\title{
Decision Support System Budget Allocation Fund Village With AHP method (Analytic Hierarchy Process) In the village of beehive
}

\author{
Ilham Pramuja Nasution ${ }^{1}$, Arjon Samuel Sitio ${ }^{2}$ \\ ${ }^{1.2}$ Informatics Engineering Study Program, STMIK Pelita Nusantara, Jl. St. Iskandar Muda 1 \\ Medan, North Sumatra, Indonesia, 20154 \\ E-mail: ilhamham013@gmail.com
}

\begin{abstract}
The budget allocation of a village fund is very important and take big effect to village progress Because the office to distribute the tax result for village development. But, that allocation is not accurately. Therefore there was design a system to support a decision a budget allocation of village funds by using an Analytical Hierarchy Process (AHP) method. This research done to the make-easy an office village in budgeting is the allocation of village funds. An method of Analytical Hierarchy Process (AHP) is one of a method known as important as the highest level. An AHP method is look for the best alternative. So,
\end{abstract}

Keywords : Allocation, Decision Support System, AHP

\section{Introduction}

Developments in information technology and information systems are so central in today's era of making almost all aspects of life can not be spared from the use of a common computer device komputer.Penggunaan is the use of computers in an enterprise where one of the sources of information in the most influential organization of its existence.

The budget allocation of the Village Fund (ADD) financial budget given by government to the village, the which is where the source of taste of various local taxes and financial fund perimbanganpusat and regions received by the District. Minister in accordance with regulations in the State No. 37 of 2007 on the guidelines pengelolahan finance village in Article 18 states that, "The allocation of funds the village comes from the budget of the District / Municipal sourced from funds perimbanganpusat financial and Regions received by District / City sourced from the fund balance of the financial center and area received by District / City to the Village at least $10 \%$ (ten percent) $"$.

Implementation of the Village Fund Allocation (ADD) in the village is intended to support and fund programs in the village of Desa penyelanggaran and implementation activities, community development and empowerment berdasarakan meeting results in leveling tersebutuntuk village building the village.

The village head is still doing the allocation of budgetary funds by consensus to the community village and hamlet head so it takes quite a long time, and keakurat the data is still lacking. This causes the amount of funds Obtained yangdapat still inaccurate and still manually.

\section{Theory}

\section{A. Decision Support Systems (DSS)}

DSS is an interactive information providing information, modeling, and pemanipulasi data.Sistem used to aid decision-making in situations of semi-structured and unstructured situations, where no one knows for sure how the decision should be made (Dr.Kursrini, M. Kom, 2017: 15).

\section{B. Analytic Hierarchy Process (AHP)}

According to Dicky Nofriansyah, Comm., M. Kom. \& Prof. Dr. Sarjon Defit, Skom., M.Sc. (2017: 57), 'MethodsProcess Analytical Hierarcy(AHP) is one method of decision support system is unique roomates Compared to others. This is Because The weighting of the criteria, the weighting of each criterion is not determined in advance but is determined using a formula of this method is based on priority (level of importance) are sourced from nature perceptional tabel.Metode a method, the which means that the importance of an alternative criterion depends viewpoint or perspective in judging someone.

According to Dr. Kusrini, M.Kom (2017: 135), the steps in the method of Analytic Hierarchy Process (AHP) include:

a. Defining the problem and Determine the desired solution, and then draw up a hierarchy of problems faced 
b. Determining the priority elements

c. synthesis

d. measuring consistency

e. Calculate Consistency index (Ci) with the formula:

Where $\mathrm{n}=$ number of elements

$$
C i=(\lambda m a k s-n) / n
$$

f. Calculate the ratio of consistency / Consistency Ratio (RI) with the formula:

$$
C R=\mathbf{C I} / \mathbf{R C}
$$

Checking konsistensi.Jika value is more than $10 \%$, then the judgment must be corrected assessment data. But if consistency (CI / CR) is less than or equal to 0.1 , then the calculation must be stated Correctly.

\section{Results and Discussion}

\section{A. problem analysis}

Budget allocation decision support system of the Village Fund With AHP method (Analytic Hierarchy Process) In the village of Hierarcy Sialang.Analytical Process (AHP) is one method of decision support system that is unique Compared to others.

This is Because The weighting of the criteria, the weighting of each criterion is not determined in advance but is determined using a formula of this method is based on priority (level of importance) are sourced from nature perceptional tabel.Metode a method, the which means that the importance of an alternative criterion depends viewpoint or perspective in judging someone.

\section{B. Discussion}

The steps in this method are as follows:

a) Defining the problem danmenetukan desired solution.

In Determining the allocation of the village, it can be broken down into elements Several items, namely the criteria and alternatives. As for the criteria in Determining the allocation of the village are:

- Area

The sub-criteria of KriteriaLuas Area in Determining the allocation of the village as follows, Area:

$=40 \mathrm{H} 69 \mathrm{H}$ A- A : Just Need

$=70 \mathrm{H}$ A- 99HA: Requires

$=100 \mathrm{ha}-130 \mathrm{H}$ A: It Requires

\ Community needs

Criteria Requirements Peoples, in Determining the allocation of the village as follows:

Community Needs:

$=0-3:$ Requires Enough

$=4-6:$ Requires

$=7-10$ : It Requires

$\otimes$ Peoples jobs,

Employment criteria Peoples, in Determining the allocation of the village as follows:

Public Works:

$=$ Employee $\quad:$ Just Need

$=$ Traders $\quad:$ Requires

$=$ Farmers $\quad:$ Urgently require

囚 type Development

Criteria in Determining the type of Development Appropriations village as follows:

Development Type:

$=$ General : Just Need

$=$ Infrastructure $:$ Requires

$=$ Clothing Food: It Requires

$\otimes$ total population

Population Determining criteria in the allocation of the village as follows:

Total population:

$=150$ cc -199 cc: Just Need

$=200 \mathrm{cc}-249 \mathrm{cc}:$ Requires

$=250$ and above : Urgently require

b) Creating a Hierarchical Structure 


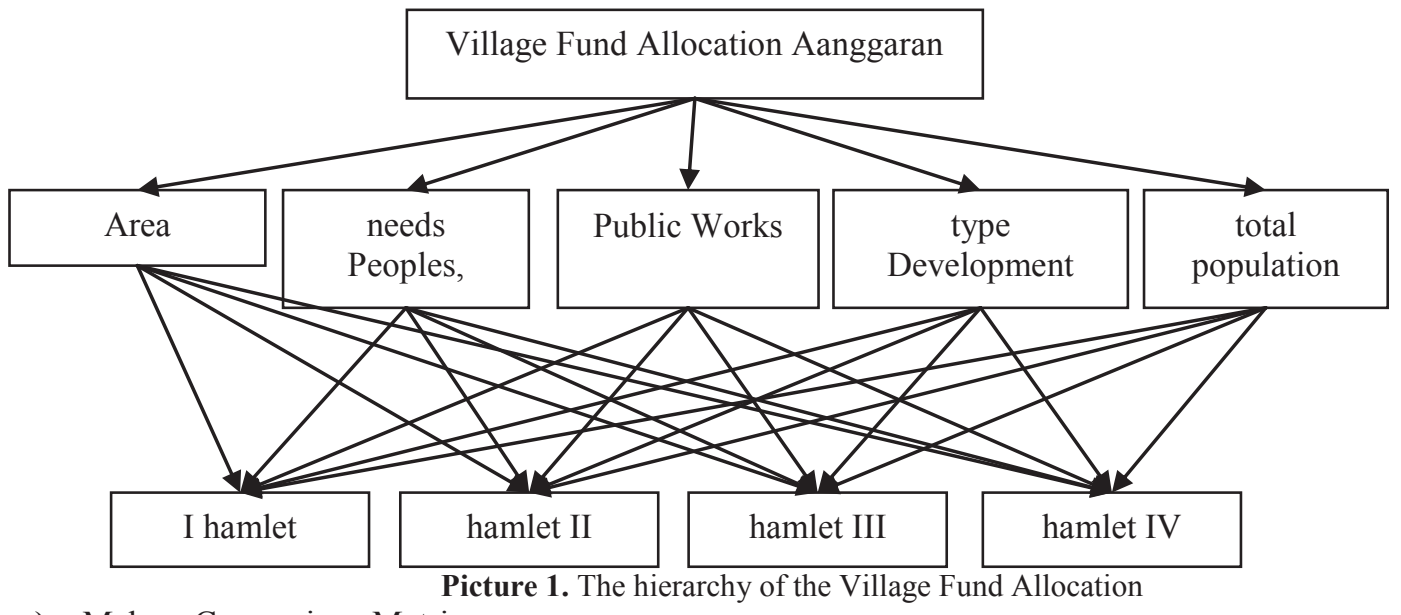

c) Make a Comparison Matrix

Table 1.

Pairwise Comparison Assessment Scale

\begin{tabular}{cl}
\hline The intensity of Interests & \\
\hline 1 & Both elements are equally important. \\
3 & Elements that one a little bit more important \\
Than other elements. & information \\
The intensity of Interests & One element penitng Clearly more absolute than any other element. \\
7 & One absolutely essential element of the other elements. \\
$2,4,6,8$ & Value - a value between two values related considerations \\
reverse & If activity i got one point Compared with activity $\mathrm{j}$, then $\mathrm{j}$ have the opposite \\
& values Compared to $\mathrm{i}$.
\end{tabular}

d) MembuatPrioritasKriteria

\ Make a Comparison Matrix

Table 2

Comparison matrix

\begin{tabular}{lccccc}
\hline \multicolumn{1}{c}{ criteria } & Area & $\begin{array}{c}\text { Community } \\
\text { needs }\end{array}$ & public Works & $\begin{array}{c}\text { type } \\
\text { Development }\end{array}$ & $\begin{array}{c}\text { total } \\
\text { population }\end{array}$ \\
\hline Area & $1: 00$ & $=1 / 50: 20$ & $=1 / 30: 33$ & $=1 / 50: 20$ & $=1 / 30: 33$ \\
Community & $5: 00$ & $1: 00$ & $3: 00$ & $=1 / 50: 20$ & $=1 / 30: 33$ \\
needs & $3: 00$ & $=1 / 30: 33$ & $1: 00$ & $=1 / 20: 50$ & $=1 / 50: 20$ \\
public Works & $5: 00$ & $5: 00$ & $2: 00$ & $1: 00$ & $=1 / 30: 33$ \\
type of & $3: 00$ & $3: 00$ & $5: 00$ & $3: 00$ & $1: 00$ \\
development & $\mathbf{1 7 : 0 0}$ & $\mathbf{9 : 5 3}$ & $\mathbf{1 1 : 3 3}$ & $\mathbf{4 . 9 0}$ & $\mathbf{2 : 2 0}$ \\
total population & & & & & \\
amount & & &
\end{tabular}

information:

$\bigotimes$ Row 2 column 2, Total Area - Total Area value ratio of 1 means the two elements are equally important.

$\bigotimes$ Row 2 column 3, Total Area - Needs Peoples, comparison =1/50:20, the mean area element Area is more important than the needs of the people element.

\ Row 2 column 4, Total Area - Works communities ratio $=1 / 30.33$, Total Area means the element slightly less important than job element Peoples,

囚 Row 2 column 5, Total Area - Type Development ratio $=1 / 50.20$, Total Area means the element is not more important than the element type Development

$\otimes$ Row 2 column 6, Total Area - Total Population ratio $=1 / 30.33$, Total Area means the elements a little more important than the element of Population.

After normalization value comparison is completed then the sum of comparison values each - each column, to a two column Total Area: $1+5+3+5+3=17$, and for the column three Community Needs: $1+0.33+0.20$ $+5+3=9.53$, and for the four columns of Public Works: $0.33+3+1+2+5=11.33$, and for the five columns Building type: $0,33+0.33+0.20+0.33+1=4.90$, and for the six columns Population: $0.33+0.33+0.20+$ $0.33+1=2.20$, could seen from table 4.4 comparison matrix.

$\otimes \quad$ Doing Comparison Troubled 
Table 3.

Troubled comparison

\begin{tabular}{|c|c|c|c|c|c|c|c|}
\hline criteria & Area & $\begin{array}{l}\text { Community } \\
\text { needs }\end{array}$ & $\begin{array}{l}\text { Peoples } \\
\text { jobs, }\end{array}$ & $\begin{array}{c}\text { type } \\
\text { Developm } \\
\text { ent }\end{array}$ & $\begin{array}{c}\text { total } \\
\text { population }\end{array}$ & $\begin{array}{l}\text { the value } \\
\text { of the } \\
\text { number of } \\
\text { lines }\end{array}$ & $\begin{array}{c}\text { avera } \\
\text { ge }\end{array}$ \\
\hline Area & $\begin{array}{l}1 / 17= \\
0: 06\end{array}$ & $0: 20 / 9: 53=0: 02$ & $\begin{array}{c}12: 33 / 11: 33= \\
0: 03\end{array}$ & $\begin{array}{c}0: 20 / 4.90= \\
0: 04\end{array}$ & $\begin{array}{c}0: 33 / 2: 20= \\
0: 15\end{array}$ & $0: 30$ & 0:06 \\
\hline $\begin{array}{l}\text { Peoples } \\
\text { needs, }\end{array}$ & $\begin{array}{l}5 / 17= \\
0: 29\end{array}$ & $1 / 9: 53=0: 10$ & $\begin{array}{c}3 / 11: 33= \\
0: 26\end{array}$ & $\begin{array}{c}0: 20 / 4.90= \\
0: 04\end{array}$ & $\begin{array}{c}0: 33 / 2: 20= \\
0: 15\end{array}$ & 0.86 & $0: 17$ \\
\hline $\begin{array}{c}\text { Peoples } \\
\text { jobs, }\end{array}$ & $\begin{array}{l}3 / 17= \\
0: 18\end{array}$ & $0: 33 / 9: 53=0: 03$ & $\begin{array}{c}1 / 11: 33= \\
0: 09\end{array}$ & $\begin{array}{c}0: 50 / 4.90= \\
0: 10\end{array}$ & $\begin{array}{c}0: 20 / 2: 20= \\
0: 09\end{array}$ & $0: 49$ & $0: 10$ \\
\hline $\begin{array}{c}\text { type } \\
\text { Developme } \\
\text { nt }\end{array}$ & $\begin{array}{l}5 / 17= \\
0: 29\end{array}$ & $5 / 9: 53=0: 52$ & $\begin{array}{c}2 / 11: 33= \\
0: 18\end{array}$ & $\begin{array}{c}1 / 4.90= \\
0: 20\end{array}$ & $\begin{array}{c}0: 33 / 2: 20= \\
0: 15\end{array}$ & $1: 35$ & $0: 27$ \\
\hline $\begin{array}{c}\text { total } \\
\text { population }\end{array}$ & $\begin{array}{l}5 / 17= \\
0: 18 \\
\end{array}$ & $3 / 9: 53=0: 31$ & $\begin{array}{c}5 / 11: 33= \\
0: 44\end{array}$ & $\begin{array}{c}3 / 4.90= \\
0.61\end{array}$ & $\begin{array}{c}1: 00 / 2: 20= \\
0: 45\end{array}$ & 2:00 & $0: 40$ \\
\hline
\end{tabular}

Q Calculating the Value eigenvectors Each Matrix

Table 4.

Value eigenvectors

\begin{tabular}{|c|c|}
\hline lambda Max & 5.98 \\
\hline $\mathrm{Ci}$ & $0: 24$ \\
\hline $\mathrm{cr}$ & $0: 22$ \\
\hline
\end{tabular}

The formula: $\mathrm{Ci}=(\lambda \max -\mathrm{n}) /(\mathrm{n}-1)$

$$
\mathrm{N}=5
$$

$\lambda \max =($ Number comparison matrix column $*$ Average - Average $)$

$$
\begin{aligned}
& =(17.00 * 0.6)+(9.53 * 0.17)+(11.33 * 0.10)+(4.90 * 0.27)+(2.20 * 0.40) \\
& =5,98
\end{aligned}
$$

$\mathrm{CI}=(\wedge$ maks $-\mathrm{n}) /(\mathrm{n}-1)$

$=(5,98-5) /(5-1)$

$=0,24$

$\mathrm{CR}=(\mathrm{CI} / \mathrm{IR})$

$=0,24 / 1: 12$

$=0,22$

If the calculation results $\mathrm{CR}<0.1=0: 22<0.1$ then the ratio of the consistency of Reviews These calculations can be accepted.

After It is also calculated in accordance priority sub-criteria such as the above steps are. Adapaun step sub priority criteria, the following criteria:

e) Calculating Priority Criteria Sub Criteria From Total Area

\ Make a Comparison matrix

Table 5

Comparison Matrix Total Area

\begin{tabular}{lrrr}
\hline \multicolumn{1}{c}{ criteria } & Urgently require & need & \multicolumn{1}{c}{ requires enough } \\
\hline Urgently require & $1: 00$ & $3: 00$ & $5: 00$ \\
need & $=1 / 30: 33$ & $1: 00$ & $3: 00$ \\
requires enough & $=1 / 50: 20$ & $=1 / 30: 33$ & $1: 00$ \\
amount & $1: 53$ & $4: 33$ & $9: 00$ \\
\hline
\end{tabular}

information:

\ Row 2 column 2, desperately needs - desperately need one comparison value, means that the two elements are equally important.

Q Row 2 column 3, desperately needs - requires a comparison value 3, meaning elements in desperate need of a little more important than the element of need. 
\ Row 2 column 4, is in desperate need - just needs a value ratio of 5 means very requires more important element of the element requires.

After normalization value comparison is completed then the sum value of the comparison in each column to column two Very Requires: $1+0: 33+0: 20=1.53$, and for three columns Requires: $3+1+0.33=4.33$, and for four columns, please Requires: $5+3+1=9$, can be seen in table 4.7 comparative matrix area.

\ Troubled Comparison calculate Total Area

Table 6

Troubled Comparison Total Area

\begin{tabular}{|c|c|c|c|c|c|}
\hline criteria & Urgently require & need & requires enough & $\begin{array}{l}\text { the value } \\
\text { of the } \\
\text { number of } \\
\text { lines }\end{array}$ & average \\
\hline Urgently require & 0.65 & 0.69 & $0: 56$ & 1.90 & 0.63 \\
\hline need & $0: 22$ & $0: 23$ & $0: 33$ & 0.78 & $0: 26$ \\
\hline \multirow[t]{2}{*}{ requires enough } & $0: 13$ & 0:08 & $0: 11$ & $0: 32$ & $0: 11$ \\
\hline & & & & amount & $1: 00$ \\
\hline
\end{tabular}

\ Calculating the Value eigenvectors Each Matrix

Table 7

\begin{tabular}{|c|c|}
\hline lambda max & $3: 06$ \\
\hline $\mathrm{Ci}$ & 0:03 \\
\hline $\mathrm{cr}$ & 0:05 \\
\hline
\end{tabular}

formula : $\mathrm{Ci}=(\lambda \max -\mathrm{n}) /(\mathrm{N}-1)$

$$
\mathrm{N}=3
$$

$\lambda \max =($ Number comparison matrix column $*$ Average - Average $)$

$=(1.53 * 0.63)+(4.33 * 0.26)+(9.00 * 0.11)$

$=3.06$

$$
\begin{aligned}
& \begin{aligned}
\mathrm{Cl}=(\lambda \text { maks }-\mathrm{n}) /(\mathrm{n}-1) \\
=(3,06-3) /(3-1) \\
=1.49
\end{aligned} \\
& \begin{aligned}
\mathrm{CR}=(\mathrm{CI} / \mathrm{IR}) \\
=1,49 / 0,58 \\
=0.5
\end{aligned}
\end{aligned}
$$

If the results of the calculation of $\mathrm{Cr}<0.1=0.5<0.1$ then the ratio of acceptable consistency of the calculation can be seen in Table 4.9 eigenvectors niali area.

f) Calculating Priority Sub Criteria Community Needs

\ Creating a Community Needs Comparison Matrix

Table 8

Comparison Matrix Peoples,

\begin{tabular}{llll}
\hline criteria & $\begin{array}{l}\text { Urgently } \\
\text { require }\end{array}$ & need & requires enough \\
\hline Urgently require & $1: 00$ & $5: 00$ & $7: 00$ \\
need & $0: 20$ & $1: 00$ & $3: 00$ \\
Simply take & $0: 14$ & $0: 33$ & $1: 00$ \\
amount & $1: 34$ & 6,33 & $11: 00$ \\
\hline
\end{tabular}

information:

\ Row 2 column 2, desperately needs - desperately need one comparison value, means that the two elements are equally important.

\ Row 2 column 3, urgently need - requires value ratio of 5 means very requires more important element of the element requires.

\ Row 2 column 4, is in desperate need - just requires a ratio of 7 means the element is in dire need Clearly absolutely essential element in need. 
After normalization value comparison is completed then the sum of comparison values each - each column to column two desperately need: $1+0: 20+0: 14=1.34$, and for the three columns need: $5+1+0.33=6.33$, and for the four columns requires enough: $7+3+1=11$, can be seen from the table comparison matrix 4:10 society needs.

\ $\quad$ Make Comparison Troubled Community Needs

Table 9.

Needs Troubled comparison Peoples,

\begin{tabular}{|c|c|c|c|c|c|}
\hline criteria & $\begin{array}{l}\text { Urgently } \\
\text { require }\end{array}$ & need & requires enough & $\begin{array}{l}\text { the value of } \\
\text { the number } \\
\text { of lines }\end{array}$ & average \\
\hline Urgently require & 0.74 & 0.79 & 0.64 & $2: 17$ & 0.72 \\
\hline need & $0: 15$ & $0: 16$ & $0: 27$ & $0: 58$ & $0: 19$ \\
\hline Simply take & $0: 11$ & 0:05 & 0:09 & $0: 25$ & 0:08 \\
\hline
\end{tabular}

Q Calculating the Value eigenvectors Each Matrix

Table 10

Value eigenvectors Community Needs

\begin{tabular}{|l|l|}
\hline lambda Max & $3: 11$ \\
\hline CI & $0: 06$ \\
\hline CR & $0: 10$ \\
\hline
\end{tabular}

formula : $\mathrm{Ci}=(\lambda \max -\mathrm{n}) /(\mathrm{N}-1)$

$$
\mathrm{N}=3
$$

$\lambda \max =($ Number comparison matrix column $*$ Average - Average $)$

$=(1.34 * 0.72)+(6.33 * 0.19)+(11.00 * 0.8)$

$=3: 11$

$\mathrm{Ci}=($ nmaks $-\mathrm{n}) /(\mathrm{n}-1)$

$=(3,11-3) /(3-1)$

$=006$

$\mathrm{Cr}=(\mathrm{Ci} / \mathrm{Cr})$

$=006 / 0: 58$

$=0,10$

If the results of the calculation of $\mathrm{Cr}<0.1=0: 10<0.1$ then the ratio of acceptable consistency of the calculation can be seen in Table 10 niali eigenvectors community needs.

g) Calculating Priority Sub Criteria Of Public Works

\ Make a Comparison Matrix

Table 11

Comparison Matrix Public Works

\begin{tabular}{lrrr}
\hline criteria & Urgently require & need & requires enough \\
\hline Urgently require & 1 & 2 & 5 \\
need & 0.5 & 1 & 4 \\
quite Need & 0.2 & $0: 25$ & 1 \\
amount & $\mathbf{1 . 7}$ & $\mathbf{3 : 2 5}$ & $\mathbf{1 0}$ \\
\hline
\end{tabular}

information:

\ Row 2 column 2, desperately needs - desperately need one comparison value, means that the two elements are equally important.

Q Row 2 column 3, urgently need - requires value ratio of 2, it means that the element is in dire need a little more important than the element requires

$\bigotimes$ Row 2 column 4, is in desperate need - just needs a value ratio of 5 means very requires more important element of the element requires.

After normalization value comparison is completed then the sum of comparison values each - each column to column two desperately need: $1+0: 05+0: 02=1.7$, and for the three columns need: $2+1+0.25=3.25$, and untukkolom four reasonably require: $5+4+1=10$, can be seen from the table 4:13 Matrisk job comparison masyrakat

- Make Troubled Comparison Matrix

Calculating the Value eigenvectors Each Matrix 
Table 12

Troubled Comparative Public Works

\begin{tabular}{lcrrrr}
\hline \multicolumn{1}{c}{ criteria } & very Membtuhkan & need & requires enough & $\begin{array}{c}\text { Value } \\
\text { Number } \\
\text { of Rows }\end{array}$ & \multicolumn{2}{c}{$\begin{array}{c}\text { Average } \\
\text { Urgently require }\end{array}$} & & $0: 59$ & 0.62 & 0.5 & 1.70 & $0: 57$ \\
need & $0: 29$ & $0: 31$ & 0.4 & $1: 00$ & $0: 33$ \\
requires enough & $0: 12$ & $0: 08$ & 0.1 & $0: 29$ \\
\hline
\end{tabular}

Table 12

Value eigenvectors Public Works

\begin{tabular}{|l|l|}
\hline lambda max & $3: 03$ \\
\hline $\mathrm{Ci}$ & $0: 02$ \\
\hline $\mathrm{cr}$ & $0: 03$ \\
\hline
\end{tabular}

formula $: \mathrm{Ci}=(\lambda \max -\mathrm{n}) /(\mathrm{N}-1)$

$$
\mathrm{N}=3
$$

$\lambda \max =($ Number comparison matrix column $*$ Average - Average $)$

$$
\begin{aligned}
& =(1.7 * 0.57)+(3.25 * 0.33)+(10.00 * 0.10) \\
& =303
\end{aligned}
$$$$
\mathrm{Ci}=(\lambda \text { maks }-\mathrm{n}) /(\mathrm{n}-1)
$$$$
=(3,03-3) /(3-1)
$$$$
=0: 02
$$

$\mathrm{Cr}=(\mathrm{Ci} / \mathrm{Cr})$

$$
\begin{aligned}
& =0,02 / 0,58 \\
& =0.3
\end{aligned}
$$

If the results of the calculation of $\mathrm{Cr}<0.1=0.3<0.1$ then the ratio of acceptable consistency of the calculation can be seen in Table 12 niali eigenvectors Community job.

h) Calculating Priority Criteria Sub Type Development

- Make a Comparison Matrix

Table 13

Comparison Matrix Development Type

\begin{tabular}{lrrr}
\hline \multicolumn{1}{c}{ criteria } & Urgently require & need & requires enough \\
\hline Urgently require & 1 & 3 & 5 \\
need & $=1 / 30: 33$ & $1: 00$ & 3 \\
requires enough & $=1 / 50: 20$ & $=1 / 30: 33$ & 1 \\
amount & $1: 53$ & $4: 33$ & 9 \\
\hline
\end{tabular}

information:

\ Row 2 column 2, desperately needs - desperately need one comparison value, means that the two elements are equally important.

$\otimes$ Row 2 column 3, desperately needs - requires a comparison value 3, meaning elements in desperate need of a little more important than the element of need.

\ Row 2 column 4, is in desperate need - just needs a value ratio of 5 means very requires more important element of the element requires.

After normalization value comparison is completed then the sum of comparison values each - each column to column two desperately need: $1+0: 33+0: 20=1.53$, and for the three columns need: $3+1+0.33=4.33$, and for the four columns requires enough: $5+3+1=9.00$, can be seen from the table 4:17 Matrisk comparison type

\begin{tabular}{|c|c|c|c|c|c|}
\hline criteria & Urgently require & need & requires enough & $\begin{array}{l}\text { the value } \\
\text { of the } \\
\text { number } \\
\text { of lines }\end{array}$ & average \\
\hline Urgently require & 0.65 & 0.69 & $0: 56$ & 1.90 & 0.63 \\
\hline need & $0: 22$ & $0: 23$ & $0: 33$ & 0.78 & $0: 26$ \\
\hline requires enough & $0: 13$ & 0:08 & $0: 11$ & $0: 32$ & $0: 11$ \\
\hline
\end{tabular}
of development.

- Doing Comparison Troubled

Table 14

Troubled Comparison Type Development 
- Calculating the Value eigenvectors Each Matrix

Table 15

Value eigenvectors Type Development

\begin{tabular}{|l|l|}
\hline lambda max & $3: 06$ \\
\hline $\mathrm{Ci}$ & $0: 03$ \\
\hline $\mathrm{cr}$ & $0: 05$ \\
\hline
\end{tabular}

formula : $\mathrm{Ci}=(\lambda \max -\mathrm{n}) /(\mathrm{N}-1)$

$$
\mathrm{N}=3
$$

$\lambda \max =($ Number comparison matrix column $*$ Average - Average $)$

$$
=(1.53 * 0.63)+(4.33 * 0.26)+(9.00 * 0.11)
$$$$
=306
$$$$
\mathrm{Ci}=(\lambda \text { maks }-\mathrm{n}) /(\mathrm{n}-1)
$$$$
=(3,06-3) /(3-1)
$$$$
=1.49
$$

$\mathrm{Cr}=(\mathrm{Ci} / \mathrm{Cr})$

$$
\begin{aligned}
& =1,49 / 0,58 \\
& =005
\end{aligned}
$$

If the results of the calculation of $\mathrm{Cr}<0.1=0.5<0.1$ then the ratio of acceptable consistency of the calculation can be seen in Table 15 niali eigenvectors Type Development.

i) Calculating Priority Sub Criteria Population

- Make a Comparison Matrix

Table 16

Comparison Matrix Population

\begin{tabular}{lrrr}
\hline \multicolumn{1}{c}{ criteria } & Urgently require & need & requires enough \\
\hline Urgently require & 1 & 3 & 5 \\
need & $0: 33$ & $1: 00$ & 3 \\
requires enough & $0: 20$ & $0: 33$ & 1 \\
amount & $1: 53$ & $4: 33$ & 9 \\
\hline
\end{tabular}

information:

\ Row 2 column 2, desperately needs - desperately need one comparison value, means that the two elements are equally important.

$\otimes$ Row 2 column 3, desperately needs - requires a comparison value 3, meaning elements in desperate need of a little more important than the element of need.

Q Row 2 column 4, is in desperate need - just needs a value ratio of 5 means very requires more important element of the element requires.

After normalization value comparison is completed then the sum of comparison values each - each column to column two desperately need: $1+0: 33+0: 20=1.53$, and for the three columns need: $3+1+0.33=4.33$, and for the four columns requires enough: $5+3+1=9.00$, can be seen from the table 4:20 Matrisk comparison population.

\begin{tabular}{|c|c|c|c|c|c|}
\hline criteria & Urgently require & need & requires enough & $\begin{array}{c}\text { The } \\
\text { value of } \\
\text { the } \\
\text { number } \\
\text { of lines }\end{array}$ & Average \\
\hline Urgently require & 0.65 & 0.69 & $0: 56$ & 1.90 & 0.63 \\
\hline need & $0: 22$ & $0: 23$ & $0: 33$ & 0.78 & $0: 26$ \\
\hline requires enough & $0: 13$ & $0: 08$ & $0: 11$ & $0: 32$ & $0: 11$ \\
\hline
\end{tabular}

- Doing Comparison Troubled

Table 17

Comparison Troubled Population

- Calculating the Value eigenvectors Each Matrix 


\section{Table 18}

Value eigenvectors Population
\begin{tabular}{|l|l|}
\hline lambda max & $3: 06$ \\
\hline $\mathrm{Ci}$ & $0: 03$ \\
\hline $\mathrm{cr}$ & $0: 05$ \\
\hline
\end{tabular}

formula : $\mathrm{Ci}=(\lambda \max -\mathrm{n}) /(\mathrm{N}-1)$

$$
\mathrm{N}=3
$$

$\lambda \max =($ Number comparison matrix column $*$ Average - Average $)$

$$
\begin{aligned}
& =(1.53 * 0.63)+(4.33 * 0.26)+(9.00 * 0.11) \\
& =306
\end{aligned}
$$

$$
\mathrm{Ci}=(\lambda \text { maks }-\mathrm{n}) /(\mathrm{n}-1)
$$$$
=(3,06-3) /(3-1)
$$$$
=1,49
$$

$$
\mathrm{Cr}=(\mathrm{Ci} / \mathrm{Cr})
$$$$
=1,49 / 0,58
$$$$
=0.5
$$

If the results of the calculation of $\mathrm{Cr}<0.1=0.5<0.1$ then the ratio of acceptable consistency of the calculation can be seen in Table 4:22 niali eigenvectors population.

j) Counting Results

After doing the criteria and sub-criteria decision mentukan results.

Table 19

Results value

\begin{tabular}{ccccc}
\hline Area & Peoples needs, & Peoples jobs, & type Development & total population \\
\hline $0: 06$ & $0: 17$ & $0: 10$ & $0: 27$ & $0: 40$ \\
Urgently require & Urgently require & Urgently require & Urgently require & Urgently require \\
0.63 & 0.72 & $0: 57$ & 0.63 & 0.63 \\
need & need & need & need & need \\
$0: 26$ & $0: 19$ & $0: 33$ & $0: 26$ & $0: 26$ \\
enough & enough & enough & enough & enough \\
$0: 11$ & $0: 08$ & $0: 10$ & $0: 11$ & $0: 11$ \\
\hline
\end{tabular}

information:

\ 12:06 Value of Total Area Obtained from value - average comparison problematic can be seen fromTable 4.5 Comparison of Problematic.

\ 0.63 Value of Highly Requires Obtained from value - average comparison problematic area can be seen from the Area Table 4.8 Comparison of Total Area Problem.

\ 0:26 value of Need Obtained from value - average comparison problematic area can be seen from the Area Table 4.8 Comparison of Total Area Problem.

\ 12:11 Value of Adequate Obtained from value - average comparison problematic area can be seen from the Area Table 4.8 Comparison of Total Area Problem.

k) Calculating Priority Outcomes

The final result of the calculation of all criteria and sub-criteria that already in the set and has been made.

\section{Result}

Table 20

Priority Outcomes

\begin{tabular}{lccccccc}
\hline \multicolumn{1}{c}{ name } & Area & $\begin{array}{c}\text { needs of } \\
\text { society }\end{array}$ & $\begin{array}{c}\text { Peoples } \\
\text { jobs, }\end{array}$ & $\begin{array}{c}\text { type } \\
\text { pembagunan }\end{array}$ & $\begin{array}{c}\text { total } \\
\text { population }\end{array}$ & Total & information \\
\hline I hamlet & $0: 01$ & $0: 03$ & $0: 03$ & $0: 03$ & $0: 10$ & 0.2 & not feasible \\
hamlet II & $0: 01$ & $0: 01$ & $0: 06$ & $0: 17$ & $0: 04$ & $0: 29$ & not feasible \\
hamlet III & $0: 04$ & $0: 12$ & $0: 06$ & $0: 07$ & $0: 04$ & $0: 33$ & not feasible \\
hamlet IV & $0: 04$ & $0: 12$ & $0: 03$ & $0: 17$ & $0: 25$ & 0.61 & worthy \\
\hline
\end{tabular}

information:

$\nabla$ hamlets $\mathrm{I}=0: 01$ is Obtained from the average criteria area * average sub-criteria reasonably require $=0: 06 *$ $0: 11$ 
\ II $=0: 01$ hamlet is Obtained from the average criteria area * average sub-criteria reasonably require $=0: 06 *$ $0: 11$

$\otimes$ hamlet III $=0: 04$ Obtained from an average of broad criteria areas * average sub-criteria reasonably require $=0,0,63 * 0: 11$

\ IV $=0: 04$ hamlet is Obtained from the average area of criteria, sub-criteria $*$ Average reasonably require $=$ $0,0,63 * 0: 11$

\section{Conclusion}

Based on the discussion of the research, it was concluded as follows:

a) This system aims to assist in decision making for the allocation of budget funds a good village to expedite work at the village office.

b) In this calculation method research Analytucal Hierarchy Process(AHP).

c) Based on calculations of the data allocation of budgetary funds, the which received the most important village is the hamlet IV with the most important value $=0.61$ Eligible.

\section{Reference}

[1] Ari Chandra Kirana, "Sistem Pendukung Keputusan MenentukanTeknisiMesin EDC ( Electronic Data Capture) Terbaik Menggunakan Metode Analyrical Hierarchy Process (AHP)", Pelita Informatika Budi Darma, 2014, 2301 9425.

[2] Ariani Susanti, "Perancangan Sistem Pendukung Keputusan PenentuanJurusanSiswa SMA Negeri 2 Kuta Cane Berbasis Web Dengan Mengguanakan MetodeAnalyrical Hierarchy Process (AHP)", PelitaInformatika Budi Darma, 2014, 2301-9425.

[3] Bardansyah, "Sistem Pendukung Keputusan Penentuan Sekolah Favorit Tingkatan Sekolah Menengah Pertama Swasta dengan Menggunakan Metode Analyrical Hierarchy Process", Pelita Informatika Budi Darma, 2014, 23019425.

[4] Dicky Nofriansyah, Sarjon Defit, 2017. Multi Criteria Decision Making (MCDM) Pada Sistem Pendukung Keputusan.Yogyakarta: Deepublish Publisher.

[5] Edianto Berutu, "Sistem Pendukung Keputusan Pengangkatan Karyawan Tetap Dengan Metode Analyrical Hierarchy Process (AHP) Pada Pt. Perkebunan Lembah Bhakti Provinsi NAD Kab. Aceh Singkil", Pelita Informatika Budi Darma, 2014, 2301-9425.

[6] Ermawati, "Sistem Pendukung Keputusan Pemilihan Pemilihan Calon Peserta Cerdas Cermat Dengan Metode Analyrical Hierarchy Process (AHP)", Pelita Informatika Budi Darma, 2014, 2301-9425.

[7] Intan Pratiwi, "Sistem Pendukung Keputusan Pemilihan Rumput Terbaik Untuk Pembuatan Taman Dengan Metode Analyrical Hierarchy Process (AHP)", Pelita Informatika Budi Darma, 2014, 2301-9425.

[8] Jubilee Enterprise, 2018.HTML, PHP, dan MySQL untukPemula, Jakarta: Gramedia.

[9] LinaYanta Panggabean,"Sistem Pendukung Keputusan Pemilihan Orthodontik (Behel) Pada Pt.Cobta Dental Cabang Medan Menggunakan Metode Analyrical Hierarchy Process", PelitaInformatika Budi Darma, 2014, 2301 9425.

[10] Melva Deli Yanti Lumban Raja, "Sistem Manajemen Download Dalam Upaya Meminimalisir Pemborosan Bandwidth Menggunakan Metode Analyrical Hierarchy Process (AHP)", Pelita Informatika Budi Darma, 2014, 2301-9425.

[11] Sylvia Hartati Saragih,"Penerapan Metode Analyrical Hierarchy Process (AHP Pada Sistem Pendukung Keputusan Pemilihan Laptop)", Pelita Informatika Budi Darma, 2014, 2301-9425.

[12] Terta Ganda, "Sistem Pendukung Keputusan Untuk Menentukan Penerima Bantuan Sosial Tahunan Dari Perusahaan Dengan Metode Analyrical Hierarchy Process", Pelita Informatika Budi Darma, 2014, 2301-9425. 